\title{
BAHASA SUNDA CIREBON DI KECAMATAN DUKUPUNTANG KABUPATEN CIREBON; KAJIAN GEOGRAFI DIALEK
}

\author{
Nana Triana Winata \\ Program Studi Pendidikan Bahasa dan Sastra Indonesia, FKIP, Unwir, Indramayu \\ pos-el: nanawinata26@gmail.com
}

\begin{abstract}
ABSTRAK
Penelitian ini berjudul "Bahasa Sunda Cirebon di Kecamatan Dukupuntang Kabupaten Cirebon: Kajian Geografi Dialek". Tujuan penelitian ini adalah mendeskripsikan kosakata bahasa Sunda Cirebon di Kecamatan Dukupuntang, mengetahui berapa banyak kosakata khas bahasa Sunda di Kecamatan Dukupuntang, dan memetakan kosakata bahasa tersebut. Dari pemetaan unsur bahasa diperoleh gambaran bahwa sebaran unsur bahasa berbeda-beda, terutama desa yang menggunakan BJC. Ada beberapa kosakata yang merupakan bahasa khas di Kecamatan Dukupuntang.

Metode yang digunakan dalam penelitian ini adalah metode deskriftif kualitatif, yaitu mendefinisikan data, sebagaimana terdapat di lokasi penelitian. Metode ini dilakukan melalui pengumpulan data dengan cara observasi langsung di lapangan dan wawancara, manusia sebagai pengumpul data utama. Sumber data dalam penelitian ini adalah penutur bahasa Sunda di Kecamatan Dukupuntang Kabupaten Cirebon (BSC). Dari satu kecamatan ini dipilih tujuh desa sebagai sampel yang diteliti, yakni mengambil dua orang informan dari setiap desa.

Hasil penelitian didapat daerah pakai unsur Bahasa Sunda Bandung (BSB) ditemukan di desa Mandala. Daerah pakai kosakata Bahasa Sunda Cirebon (BSC) ditemukan di desa Sindang Jawa, desa Girinata, dan desa Cipanas. Desa yang lainnya menggunakan bahasa sehari-harinya adalah bahasa Jawa Cirebon.

Kata kunci: Bahasa Sunda Cirebon, Kecamatan Dukupuntang, Kabupaten Cirebon, Kajian Geografi Dialek.

\section{PENDAHULUAN}

Bahasa adalah suatu media yang digunakan oleh masyarakat yang satu dengan yang lain. Bahasa sebagai sistem lambang bunyi yang bersifat arbitrer, arbitrary berasal dari slected at random and without reason, dipilih

secara acak tanpa alasan. Ringkasnya manasuka berarti seenaknya, asal bunyi, tidak ada hubungan logis dengan kata-kata sebagai simbol dengan yang disimbolkannya (Alwasilah, 2011: 89). Bahasa terdiri atas kata-kata atau kumpulan kata yang masing-masing memiliki makna.
\end{abstract}


Bahasa terdiri atas bahasa lisan dan bahasa tulisan. Bahasa lisan merupakan bahasa primer, sedangkan bahasa tulisan adalah bahasa sekunder. Selain bahasa lisan dan bahasa tulisan, ada juga bahasa isyarat atau bahasa tubuh yaitu salah satu cara berkomunikasi dengan melakukan gerakan tubuh. Dengan adanya bahasa, manusia dapat mengungkapkan apa yang ada dipikirannya kepada orang lain. Bahasa merupakan sarana berkomunikasi atau berinteraksi, dengan bahasa orang menjadi tahu apa yang sedang dipikirkan orang tersebut.

Di Indonesia begitu banyak bahasa yang dipakai di setiap daerahnya, bahasa yang ada di setiap daerah di Indonesia semuanya berbedabeda. Dialek adalah bahasa sekelompok masyarakat yang tinggal di daerah tertentu. Pada dasarnya dialektologi merupakan ilmu tentang dialek, yang merupakan cabang dalam ilmu linguistik. Selain mempelajari variasi-variasi bahasa dialektologi juga membandingkan bahasa-bahasa yang masih serumpun untuk mencari persamaan atau perbedaannya. Dialek juga merupakan bahasa ibu atau yang biasa disebut dengan bahasa yang pertama kali dikenalkan kepada anak dari ibu yang melahirkannya.

Penelitian dialek geografis khususnya di desa-desa perbatasan antara dua penutur bahasa, yaitu bahasa Sunda Cirebon dan bahasa Jawa Cirebon belum banyak dilakukan, terutama mengenai dialek geografis bahasa Sunda Cirebon di Kecamatan Dukupuntang. Oleh karena itu, penelitian ini perlu dilakukan. Dalam penelitian ini akan diungkapkan variasi geografis bahasa Sunda Cirebon.

Setiap bahasa daerah pasti memiliki kekhasannya masing-masing. Termasuk di Kecamatan Dukupuntang memiliki kekhasan sendiri dalam berbahasa. Masyarakat di Kecamatan Dukupuntang yang bisa menguasi BJC dan BSC, sehingga terjadinya pertukaran atau saling meminjam bahasa yang bisa menghasilkan bahasa khas di daerah tersebut. Penulis akan mencoba melihat persamaan dan perbedaan bahasa Sunda di Kabupaten Cirebon dengan bahasa Sunda baku, berikut ini adalah contoh perbedaan dan persamaan bahasa Sunda Cirebon dengan bahasa Sunda baku.

Tabel 1.1

Perbedaan BSB dan BSC

\begin{tabular}{|c|c|c|c|}
\hline No & Bahasa Sunda Baku & Bahasa Sunda Cirebon & Arti \\
\hline 1. & Sirah & hulu' & kepala \\
\hline 2. & pant’ & laway & pintu \\
\hline 3. & sadaya & kabsh & semua \\
\hline 4. & kaleci' & pinci' & kelereng \\
\hline
\end{tabular}

Berdasarkan latar belakang yang telah diuraikan di atas, penulis akan mengadakan 
penelitian terhadap bahasa Sunda Cirebon terutama di daerah-daerah yang letaknya di perbatasan penutur bahasa Jawa Cirebon. Berdasarkan latar belakang masalah di atas. Dapat dirumuskan masalah berikut.

1. Kosakata apa saja yang terdapat dalam bahasa Sunda Cirebon di Kecamatan Dukupuntang?

2. Bagaimana distribusi geografis yang berupa kosakata bahasa Sunda Cirebon di Kecamatan Dukupuntang?

Tujuan penulisan ini untuk mendeskripsikan kosakata bahasa Sunda Cirebon di Kecamatan Dukupuntang dan memetakan kosakata bahasa Sunda Cirebon di Kecamatan Dukupuntang.

\section{METODOLOGI PENELITIAN}

Penelitian ini menggunakan metode kualitatif, yaitu dengan cara mengumpulkan data secara langsung di lokasi penelitian. Metode ini dapat dipahami dengan cara observasi langsung di lapangan, wawancara, mengumpulkan informasi, dan manusia sebagai alat yang merupakan pengumpul data utama.

Kegunaan penelitian ini merupakan penelitian dalam bidang linguistik, khususnya geogafi dialek. Penelitian ini diharapkan dapat memberikan sumbangan yang berguna bagi linguistik umumnya dan geografi dialek khususnya, termasuk ancangan dalam pengajaran dan informasi bagi penelitian lebih lanjut.

Metode dan teknik analisis data. Data lisan dikumpulkan dengan menggunakan metode pengamatan langsung di lapangan atau metode simak (Sudaryanto, 1988: 2 dalam Wahya, 1995: 16). Adapun teknik pengumpulan data yang dilakukan adalah dengan teknik pengumpulan data dan analisis data. Pada teknik pengumpulan data menggunakan simak dan cakap, yaitu dengan cara wawancara, pencatatan, perekaman dan SMS atau telepon.

Dalam penelitian ini, pengumpulan data dilakukan dengan cara wawancara berdasarkan daftar tanyaan yang telah disiapkan. Daftar tanyaan disusun berdasarkan kombinasi daftar tanyaan dan kosakata budaya dasar menurut bidang (medan makna). Yang dimaksud bidang (medan makna) adalah (a) sistem kekerabatan, (b) kata ganti dan sapaan, (c) kehidupan dan pemerintahan desa, (d) mata pencarian, (e) bagian-bagian rumah, (f) alatalat rumah, (g) alat dan bidang pertanian, (h) alat perikanan, (i) alat pertukangan, (j) keadaan alam dan bagian alam, (k) tanaman dan sayuran, (l) pohon-pohonan dan buahbuahan, (m) hewan peliharaan, (n) hewan liar dan serangga, (o) bagian tubuh, (p) makanan dan minuman, (q) sifat dan keadaan, (r) penyakit, (s) ekspresi dan kata kerja, dan (t) partikel. Kadang-kadang kita 
harus menunjuk benda yang kita tanyakan secara langsung, yakni melalui alat peraga atau gambar.

\section{HASIL DAN PEMBAHASAN}

Penelitian dialektologi bahasa Sunda di Kecamatan Dukupuntang Kabupaten Cirebon ini. Hanya mengambil 50 data kosakata. Namun tidak semua data dapat dipetakan karena informasi yang diperoleh tidak dapat menafsirkan semuanya. Dengan demikian, hasil data di lapangan tidak dicantumkan semuanya ke dalam pembahasan.

Data yang diperoleh di lapangan lebih dari 50 kosakata, tetapi hanya di ambil 50 kosakata untuk dibahas pada bab ini. Dari 50 kosakata yang diambil ini akan dibahas mengenai fonologi, morfologi, dan leksikon. Hasil dari analisis 50 kosakata itu akan di petakan. Setelah 50 kosakata itu dipetakan akan didapat beberapa bahasa khas di Kecamatan Dukupuntang.

\section{1. a. Fonem-fonem Konsonan}

Data yang disajikan berikut hanya data yang diperoleh dari lapangan.

/p/ : konsonan takbersuara, bibir letus

$\begin{array}{ll}\text { /pawon/ } & \text { 'dapur' } \\ \text { /jəmpol/ } & \text { 'ibu jari' }\end{array}$

/b/ : konsonan bersuara, bibir, letus

/bujal/ 'pusar'
/'abah/ 'kakek'
/na?ib/ 'petugas pencatat nikah'

/t/ : konsonan takbersuara, ujung lidah, letus

$\begin{array}{ll}\text { /tcre'/ } & \text { 'tiri' } \\ \text { /letah/ } & \text { 'lidah' } \\ \text { /mankat/ } & \text { 'pergi' }\end{array}$

\section{b. Fonem-fonem vokal}

/a/ : vokal tengah, rendah, takbundar

$$
\begin{array}{ll}
\text { /'adi'/ } & \text { 'adik' } \\
\text { /sampö'/ } & \text { 'singkong' } \\
\text { /mitoha/ } & \text { 'mertua' }
\end{array}
$$

/i/ $\quad$ : vokal depan, tinggi takbundar

$$
\begin{array}{ll}
\text { /'iruy/ } & \text { 'hidung' } \\
\text { /minantu'/ } & \text { 'menantu' } \\
\text { /məri'/ } & \text { 'anak bebek' }
\end{array}
$$

/u/ : vokal belakang, tinggi bundar

/'usum/ 'musim'

/jəpun/ 'cabe rawit'

/huntu'/ 'gigi'

/ə/ : vokal tengah, sedang, takbundar

/'əndi'/'mana'

$$
\text { / kamər/ 'kamar' }
$$

\section{c. Gugus Konsonan}

Gugus konsonan yang ditemukan pada data adalah konsonan letus yang diikuti oleh $\mathrm{r}$ dan 1 . berikut beberapa contoh.

$$
\begin{array}{lll}
\text { /cr/ } & : \text { /crəme'/ } & \text { 'ceremai' } \\
\text { /p1/ } & : \text { /plani'/ } & \text { 'pelangi' } \\
\text { /cl/ } & : \text { /yacləy/ } & \text { 'lompat' }
\end{array}
$$


/br/ : : /sabray/ 'cabai'

\section{d. Kontras konsonan}

Beberapa kontras konsonan dalam

wilayah ucapan yang ditemukan adalah sebagai berikut.

/p/-/b/ /paway/'orang yang mempunyai

keahlian istimewa ilmu gaib'

/baway/ 'bawang'
/t/-/d/ 'hate'/ 'hati'
/hade'/ 'bagus benar'

/w/-/y/ /hawu'/ 'tungku'

/hayu'/ 'kata antar untuk

mengajak'

\section{e. Kontras vokal}

Beberapa kontras vokal dalam wilayah ucapan yang ditemukan adalah sebagai berikut.

$\begin{array}{lll}\text { /a/-/u/ } & \text { /kidal/ } & \text { 'kiri' } \\ \text { /kidul/ } & \text { 'selatan' } \\ \text { /i/-/a/ } & \text { /bilik/ } & \text { 'anyaman yang terbuat } \\ \text { dari bambu' } & \end{array}$

/balik/ 'pulang'

\section{Pembahasan Peta}

Peta ditafsirkan dari segi gejala bahasa dan segi data kebahasaan sinkronis. Tidak semua data yang diperoleh di lapangan selama penelitian dipetakan. Dalam penelitian ini ada 50 data yang dipetakan. Data yang dipetakan berdasarkan (1) data tersebut melihatkan perbedaan atau variasi di beberapa desa yang diteliti, (2) data tersebut ditemukan di semua desa yang diteliti, (3) data tersebut umumnya dapat ditelusuri perkembangannya atau sejarahnya berdasarkan informasi yang diperoleh, dan (4) data tersebut umumnya masih memperlihatkan unsur atau jejak BS walaupun unsur atau jejak itu hanya diperlihatkan oleh data di suatu desa.

\section{Peta Fonologi}

Peta ini membahas unsur bahasa yang mengandung perbedaan yang bersifat fonologis, termasuk perbedaan yang bersifat fonemis, misalnya ditunjukkan oleh perbedaan vokal dan konsonan yang terdapat pada data. Perbedaan morfofonemis, misalnya, ditunjukkan oleh hilangnya satu vokal atau satu konsonan, penambahan satu vokal atau satu konsonan, hilangnya atau penambahan satu suku kata, atau gejala metatesis.

1. 1. ['iruy] 'hidung'

$$
\begin{array}{ll}
\text { ['iruy] } & :(\operatorname{desa} 1,2, \text { dan } 4) \\
\text { [hiruy] } & :(\operatorname{desa} 3,5,6, \text { dan } 7)
\end{array}
$$

Kata ['iruy] dalam bahasa Sunda digunakan sebagai konsep untuk menyatakan hidung. Di desa 1, 2, dan 4 dikenal dengan sebutan ['iruy], sedangkan di desa 3, 5, 6, dan 7 dikenal dengan [hiruy]. Kata ['iruy] > [hirun], adanya kata lama yaitu [hiruy] yang digunakan oleh masyarakat Kecamatan Dukupuntang khususnya yang berbahasa Sunda.

$$
\begin{aligned}
& \text { 1. 2. [həntö'] 'tidak' } \\
& \begin{array}{ll}
\text { [əntə’] } & :(\operatorname{desa} 2,4, \operatorname{dan} 5) \\
\text { [həntö’] } & :(\operatorname{desa} 1,3,6, \operatorname{dan} 7)
\end{array} \\
& \text { Kata [həntö'] dalam bahasa Sunda }
\end{aligned}
$$
digunakan sebagai konsep untuk menyatakan 
tidak. Di desa 1, 3, 6, dan 7 tidak mengalami perubahan apapun. Di desa 2, 4, dan 5, kata tersebut mengalami penghilangan fonem $/ \mathrm{h} /$ dan perubahan dari vokal /ö/ menjadi /ə/ karena desa 2, 4, dan 5 merupakan perbatasan dengan penutur BJC yang sebagian besar tidak bisa melafalkan fonem vokal /ö/.

\section{Peta Morfologi}

Peta-peta ini membahas unsur bahasa yang mengandung perbedaan yang bersifat morfologis. Contoh perbedaan morfologis ditunjukkan dengan pengulangan suku kata pertama, atau penambahan sufiks dan afiks.

1. 3. [məri'] 'anak itik'

$$
\begin{array}{ll}
\text { [məri'] } & :(\text { desa } 1,6, \text { dan } 7) \\
{[\text { məməri'] }} & :(\text { desa } 2,3,4, \text { dan } 5)
\end{array}
$$

Konsep untuk kata anak itik dalam bahasa Sunda dinyatakan dengan [məri']. Kata [məri'] dipakai di desa 1, 6, dan 7. Kata [məməri'] dipakai di desa 2, 3, 4, dan 5 yang mengalami pengulangan suku kata pertama dari kata dasar [məri'].

1. 4. [mumuñcanan] 'mata kaki'

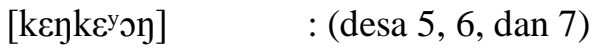

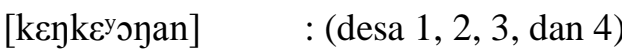

Konsep untuk kata mata kaki dalam bahasa Sunda dinyatakan dengan

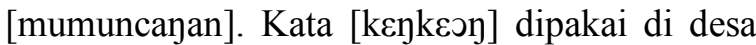
5,6 , dan 7, sedangkan di desa 1, 2, 3, dan 4

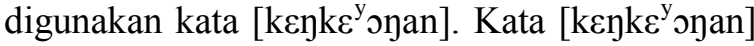
dasarnya adalah [keykeon] yang mengalami afiksasi -an menjadi [kenkeonan]. Sebagian besar Kecamatan Dukupuntang ini menggunakan kata [kenkeojan] untuk menyatakan kata mata kaki.

\section{Peta Leksikon}

Peta leksikon membahas unsur bahasa yang mengandung perbedaan yang bersifat leksikal. Perbedaan leksikal ditunjukkan oleh kosakata secara utuh.

1. [ka' mana'] 'ke mana'

$$
\begin{array}{ll}
{[\mathrm{ka} \text { ' mana'] }} & :(\text { desa } 6 \text { dan } 7) \\
{[\mathrm{ka} \text { ' 'endi'] }} & :(\text { desa } 1) \\
{[\text { kandi'] }} & :(\text { desa } 2,3,4, \text { dan } 5)
\end{array}
$$

Kata [kamana'] dalam BS untuk menyatakan ke mana, di desa 6 dan 7 menggunakan kata [kamana'], di desa 1 dikenal dengan kata [ka' 'endi'], sedangkan di desa 2, 3, 4, dan 5 dikenal dengan kata [kandi'].

2. [lintuh] 'gemuk'

$\begin{array}{ll}\text { [lintuh] } & :(\operatorname{desa} 1,3, \text { dan } 7) \\ \text { [gəndut] } & :(\operatorname{desa} 2,4,5, \text { dan } 6)\end{array}$

Kata [lintuh] dalam bahasa BS untuk menyatakan gemuk. Kata [lintuh] digunakan di desa 1, 3, dan 7. Sedangkan di desa 2, 4, 5, dan 6 menggunakan kata [gəndut], yang memiliki arti yang sama dalam BI yaitu gemuk.

\section{Daerah Pakai Unsur Bahasa}

BSC sebagai salah satu variasi geografi BS memiliki persamaan dan perbedaan dengan BSB. Tidak heran apabila banyak kosakata BSB yang juga dikenal dalam BSC atau sebaliknya walaupun dikenalnya unsur BSB di setiap desa berbeda. Salah satu perbedaan itu terjadi. Karena banyaknya kosakata pinjaman yang dipakai BJC 
oleh BSC.

Ada faktor yang menyebabkan persamaan dan perbedaan BSC dengan BSB atau BSL. Sebagaimana layaknya sebuah bahasa yang tumbuh dan berkembang di tengah-tengah pertumbuhan dan perkembangan budaya masyarakat penutur bahasa tersebut. Oleh karena itu, beberapa kata BSC tidak dikenal dalam BS di daerah lain, juga dalam BSB, juga dalam BI.

\section{Derah Pakai Kosakata BSC}

Berdasarkn penelitian, dari 50 peta yang disajikan, terdapat kosakata khas di Kecamatan Dukupuntang. Terdapat 11 kosakata khas di Kecamatan Dukupuntang, di antaranya peta (12)

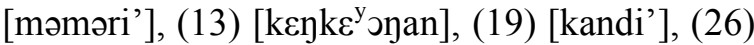
[t๕mbok], (27) [pi $\left.{ }^{\mathrm{y}} \mathrm{an}\right], \quad$ (30) [‘öcö’], (31) [rubi ${ }^{\mathrm{y}} \mathrm{ah}$, (36) [maribis], (40) [cu'win], (43) [laray], dan (48) [sabray].

Daerah pakai kosakata BSC dalam peta (12) [məməri'], yaitu desa 2, 3, 4, dan 5 .

Daerah pakai kosakata BSC dalam peta (13)

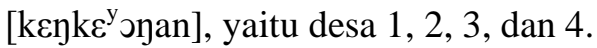

Daerah pakai kosakata BSC dalam peta (19) [kandi'], yaitu desa 2, 3, 4, dan 5 .

Daerah pakai kosakata BSC dalam peta (26) [tembok], yaitu desa 1, 3, 5, 6, dan 7 .

Daerah pakai kosakata BSC dalam peta (27) [pi ${ }^{\mathrm{y}}$ an], yaitu desa 2, 4, 5, 6, dan 7 .

Daerah pakai kosakata BSC dalam peta (30) [‘öcö'], yaitu desa 2, 4, 5, 6, dan 7 .

Daerah pakai kosakata BSC dalam peta (31) [rubi ${ }^{\mathrm{y}}$ ah], yaitu desa 2, 4, 5, 6, dan 7.
Daerah pakai kosakata BSC dalam peta (36) [maribis], yaitu desa 5, 6, dan 7.

Daerah pakai kosakata BSC dalam peta (40) [cu ${ }^{\text {win] }}$, yaitu desa 2, 4, 5, 6 dan 7.

Daerah pakai kosakata BSC dalam peta (43) [laray], yaitu desa 2, 4, 5, dan 6 .

Daerah pakai kosakata BSC dalam peta (48) [sabran], yaitu desa 1, 2, 4, dan 5 .

\section{SIMPULAN}

Berdasarkan 50 buah peta yang memuat kosakata BSC, terdapat sebelas buah kosakata bahasa Sunda khas di Kecamatan Dukupuntang,

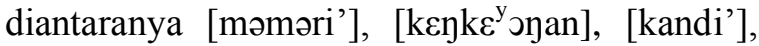
[tembok], [pi ${ }^{\mathrm{y} a n], ~[' o ̈ c o ̈ ’], ~[r u b i ~}{ }^{\mathrm{y} a h}$ ], [maribis], [cuwin], [sabray], dan [laray]. Kosakata bahasa Sunda yang ada di Kecamatan Dukupuntang yang dipengaruhi oleh bahasa Jawa Cirebon adalah kosakata yang dipakai sehari-hari oleh masyarakat Kecamatan Dukupuntang. Dari kesebelas contoh bahasa Sunda khas di Kecamatan Dukupuntang itu ada beberapa yang memiliki kesamaan dengan desa lain yang berbahasa Jawa Cirebon. Terdapat satu desa yang memiliki dua bahasa dalam percakapan sehari-hari, yakni desa Sindang Jawa. Kemungkinan besar desa Sindang Jawa ini saling meminjam atau menyerap bahasa Sunda atau bahasa Jawa.

Dari 50 buah peta unsur bahasa yang diteliti, diperoleh perbedaan unsur bahasa pada peta-peta tersebut dengan rinciaan sebagai berikut.

a). Sebanyak 11 buah peta (22\%), yaitu (01- 
11) merupakan peta yang Marsono. 1999. Fonetik. Gadjah Mada memperlihatkan perbedaan fonologis. University Press.

b). Sebanyak 7 buah peta (14\%), yaitu (1218) merupakan peta yang memperlihatkan perbedaan morfologis.

c). Sebanyak 32 buah peta (64\%), yaitu (19-50) merupakan peta yang memperlihatkan perbedaan leksikal.

\section{DAFTAR PUSTAKA}

Alwasilah, A. Chaedar. 1985. Beberapa Mazhab dan Dikotonomi Teori Linguistik. Bandung: Angkasa.

Alwasilah, A. Chaedar. 2011. Linguistik Suatu Pengantar. Bandung: Angkasa

Ayatrohaedi. 1979. Dialektologi sebuh Pengantar. Jakarta: Pusat Pembinaan dan Pengembangan Bahasa, Departemen Pendidikan dan Kebudayaan.

Chaer, Abdul. 2009. Fonologi Bahasa Indonesia. Jakarta: PT Rineka Cipta.

Chaer, Abdul dan Leonie Agustina. 2004. Sosiolinguistik (Perkenalan Awal). Jakarta: PT Rineka Cipta

Djajasudarma. T. Fatimah. 2010. "Metodologi Linguistik (Ancangan Metode Penelitian dan Kajian)”. Bandung: PT. Refika Aditama.

Keraf, Gorys. 1984. Linguistik Bandingan Historis. Jakarta: Gramedia.
Ramlan, M. 1987. Morfologi Suatu Tinjauan Deskriptif. Yogyakarta: Gadjah Mada University Press.

Sudaryanto. 1992. Metode Linguistik (Ke Arah Memahami Metode Linguistik). Yogyakarta: Gadjah Mada University Press.

Sugono, Dendy. 2003. Pedoman Penelitian Dialektologi. Jakarta: Pusat Bahasa Departemen Pendidikan Nasional.

Suwito. 1985. Pengantar Awal Sosiolinguistik. Surakarta: Henary Ofset.

Verhaar, J. W. M. 2006. Asas-asas Linguistik umum. Yogyakarta: Gadjah Mada University Press.

Wahya. 1995. "Bahasa Sunda di Kecamatan Kandanghaur dan Kecamatan Lelea Kabupaten Indramayu: Kajian Geografi Dialek”. Tesis Fakultas Sastra Universitas Padjadjaran, Bandung.

Wahya. 2005. "Inovasi dan Difusi Geografis Leksikal Bahasa Melayu dan Bahasa Sunda di Perbatasan Bogor-Bekasi: Kajian Geolinguistik”. Disertasi: Universitas Padjadjaran

Zulaeha, Ida. 2010. Dialektologi (Dialek Geografi \& Dialek Sosial). Graha Ilmu. 
